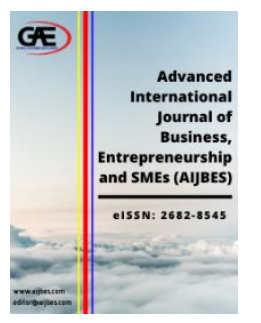

\author{
ADVANCED INTERNATIONAL JOURNAL OF \\ BUSINESS, ENTREPRENEURSHIP AND SMES \\ (AIJBES) \\ WWW.aijbes.com
}

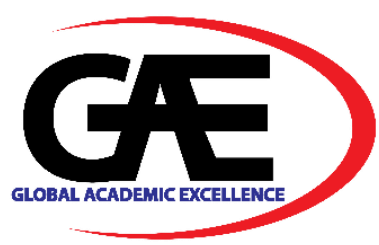

\title{
A LITERATURE REVIEW ON HOW TAX INCENTIVES COULD ASSIST INNOVATION AND SME RESEARCH ECOSYSTEM
}

\author{
Nurazwa Ahmad ${ }^{1 *}$, Nor Hazana Abdullah ${ }^{2}$, Anita Ahmad ${ }^{3}$, Ghazali Abu ${ }^{4}$
}

1 Faculty of Technology Management and Business, Universiti Tun Hussein Onn Malaysia (UTHM), Malaysia, Email: nurazwa@uthm.edu.my

2 Faculty of Technology Management and Business, Universiti Tun Hussein Onn Malaysia (UTHM), Malaysia, Email: hazana@uthm.edu.my

3 Faculty of Electrical Engineering, Universiti Teknologi Malaysia (UTM), Malaysia Email: anita@utm.my

$4 \quad$ Cluster of Business and Management, Open University Malaysia (OUM), Malaysia

Email: ghazaliabu@oum.edu.my

* Corresponding Author

\section{Article Info:}

Article history:

Received date: 27.07 .2021

Revised date: 11.08 .2021

Accepted date: 25.08.2021

Published date: 09.09.2021

\section{To cite this document:}

Ahmad, N., Abdullah, N. H., Ahmad, A., \& Abu, G. (2021). A Literature Review On How Tax Incentives Could Assist Innovation And SME Research Ecosystem. Advanced International Journal of Business, Entrepreneurship and SMEs, 3 (9), 228-243.

DOI: 10.35631/AIJBES.39016.

This work is licensed under CC BY 4.0

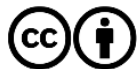

Abstract:

In an effort to foster the innovation and commercialization ecosystem in Malaysia, the government has introduced various tax mechanisms such as the allocation of funds from tax incentives to provide financial assistance to small and medium-sized enterprises (SMEs). As against large corporations which have substantial research and development budgets to start with, limited capital and financial constraints in SMEs companies hinder their capabilities to fund their own R\&D which in turn affect their innovation capabilities. This paper reviews various tax mechanisms and initiatives used by other countries to facilitate the SMEs' innovation capabilities and how universities collaborate the R\&D efforts with industries through grants and incentives. The findings are later compared to the research ecosystem in Malaysia, the government, the policy, and the challenges of implementation. It is concluded that SMEs could benefit from the spill over of funds from tax mechanisms to finance their R\&D collaboration. This government-university-industry symbiotic triple helix linkage could create a conducive research ecosystem and benefit the SMEs in innovation capabilities and product commercialization.

Keywords:

Incentives, SMEs, Financial Constraints, R\&D, Policy, Challenges, Collaboration, Triple Helix, Research Ecosystem 


\section{Introduction}

Innovation has been the subject of debate among technologies and manufacturers for decades (Nor, Bhuiyan, Said, \& Alam, 2017). Since 1994, the government have put an effort to look into the innovation activities in the manufacturing sector through the Ministry of Science, Technology and Innovation (MOSTI) and its agency which is the Malaysian Science and Technology Information Centre (MASTIC). MOSTI in currently referred as the Ministry of Energy, Science, Technology, Environment and Climate Change (MESTECC). The initiative of the ministry is known as the National Survey of Innovation (NSI) which principally done on a bi-annual or tri-annual basis. The most recent published survey was in 2015 is the NSI-7 which was carried out during 2015 until 2016. The latest survey had included the observation between three different sectors of small, medium, and large companies about the variance of their innovation activities (Ismail \& Soehod, 2014). The analyzed data showed that from 1,685 companies surveyed, $72 \%$ or 1213 companies were identified as the innovative companies and only $28 \%$ or 472 companies are non-innovative. From the 1213 innovative firms, $38 \%$ or 469 are manufacturing companies while the rest are from services sector. While, when looking from the manufacturing sector alone, from total of 681 manufacturers, $69 \%$ are innovative firms. 93\% from 469 firms are dominated by the SMEs. This figure shows the majority of SME manufacturers in Malaysia are still actively surviving and maintaining their business through innovation in the manufacture of computers, electronics, optical, food products and more.

When referring to innovation activity, it is closely related to research and development (R\&D). Since 1994, the government have put an effort to support the innovation activities in the manufacturing sector through the Ministry of Science, Technology and Innovation (MOSTI), which has been rebranded into the Ministry of Energy, Science, Technology, Environment and Climate Change (MESTECC), and its agency the Malaysia Science and Technology Information Centre (MASTIC). The trend in Malaysia shows that mostly large companies benefited more from the tax incentives offered by the government. For companies that dedicate their future's sustainability to innovation activities such as research and development, it is considered as high-risk investments that incurred spending a large amount of money. Due to limited capital and financial constraints in small and medium-sized companies, not every company has the capacity to fund their own research and development. They are required to resort external funding to support their innovation programs. As such, various mechanisms are introduced to stimulate innovative culture in government's agency as well as private sector. Selected research and development programs are being funded and various grants are introduced to facilitate new product innovation for private sectors. Governments worldwide increasingly rely on tax incentives in addition to direct support measures to promote $R \& D$ in firms and encourage innovation and economic growth. Government in several countries seek to promote $R \& D$ investment in the economy by granting a preferential tax treatment to eligible R\&D expenditure, especially those incurred by firms. As an evidence, as at 2017, 30 out of 35 OECD countries, 21 out of 28 EU countries and a few non-OECD economies provide tax relief on $R \& D$ expenditure (OECD, 2018).

A study by Lee and Lee (2007) used firm-level data to reveal that younger firms are more towards innovation than the older firms in small-sized firms. Whereas in medium and largesized firms, it shows that the older firms are more inclining towards innovation. The determinant factor for innovation has no effect on foreign-owned companies. Small-sized firms with more manpower has more probability to innovate while medium-sized firms that cater for domestic market are expected to be more innovative. Public limited companies that are medium in size are less possibility to innovate. There is a complex relationship between technological 
Volume 3 Issue 9 (September 2021) PP. 228-243

DOI 10.35631/AIJBES.39016

characteristics of industry and firms' tendency to innovate. The eagerness of medium-sized firms for innovation has a linear relationship with the higher market concentration. An another study by Lim, Lee, and Nagaraj (2012) empirically tested companies in Malaysia to find the correlation between innovation and performance. Using firm-level data, there is a connection amongst innovation investment, innovation performance and the firm performance through a multi-structural equation model. The gist of the results show that innovation is a crucial determinant factor in the performance of the firms. More investment will be poured following a successful product innovation that uplift the performance of the firm. This in turn will enhance the performance of the innovation program itself due to the sufficient funds. In other occasion, the study reveals that the size of the firms has developed differential effects on innovation input and innovation output. The firm's performance is also depending on knowledge interaction that revolves around innovation programs.

Policy makers and scholars in Malaysia are taking responsibility to comprehend the impact of innovation in manufacturing sector in Malaysia since they account for 30 percent of GDP and represents 80 percent of export of the country. The impact is still not being felt although millions of Malaysian Ringgit have been spent to support innovative products. Recent study shows that the government spent $1.3 \%$ of GDP for research programs as compared to other developed countries which spent $1.5 \%$ of their GDP for similar purposes. Figure 1 shows the progress of R\&D spending in Malaysia by sectors from 2000 until 2016. The figure displays that business enterprise (BE) sector which is the private companies had remained as the largest contributor to spur of R\&D activities in Malaysia until the recent assessed year. Business enterprise plays as the major exploiter of the year with the spending of RM10,006 million. The second highest contributor to R\&D spending is the higher learning institution (HLI) with the value of RM6,041 million. Whilst, the least contributor to the R\&D spending is government research institutes (GRI) worth RM1,627 million and non-governmental organization (NGO) worth RM12 million (MASTIC, 2019).

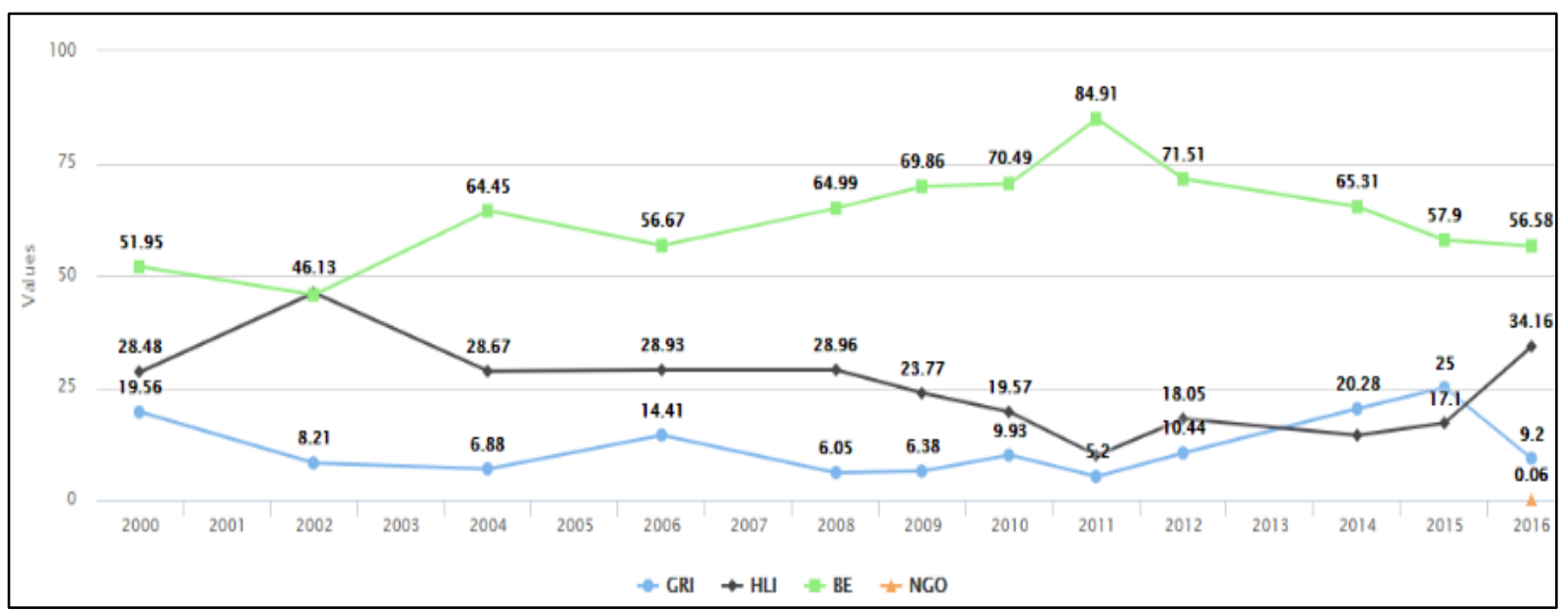

Figure 1: Expenditure on R\&D by Sectors 2000-2016 (MASTIC, 2019) 


\section{Literature Review}

\section{Research Ecosystem}

Innovation programs can be carried out and improved if there is knowledge sharing amongst universities and the affected industries (Ankrah \& Omar, 2015). Studies in this area which cover in different topics are increasing such as government support for innovation (Szczygielski, Grabowski, Pamukcu, \& Tandogan, 2017), tax incentives impact on innovation (Crespi, Giuliodori, Giuliodori, \& Rodriguez, 2016; Czarnitzki, Hanel, \& Rosa, 2011), external collaboration and firm innovation (Findik \& Beyhan, 2015). 82 percent signify 7,632 new products while 78 percent represent 4,331 significantly improved products have been developed through closed innovation which means the innovations were done internally by the company itself or company's group (Ismail \& Soehod, 2014). Chandran, Sundram, and Santhidran (2014) elaborates the findings in university-industry collaboration in R\&D activities. Universities have become the prime link with industries to collaborate in R\&D. However, the industries are offered with few tax incentives to participate in the collaboration which leave only the universities run the program. It needs a better policy to maximize the use of universities as the knowledge source to improve innovation performance and the industries that participate should be offered with better tax incentives and other financial reliefs to upgrade the industrial R\&D programs (demand side). However, it will not materialize if the industries are unwilling to capitalize on the knowledge conceived by the universities. In view of this, the universities have also the responsibility to improve their R\&D management to promote collaboration with the industries and take the initiative to complement the applied $\mathrm{R} \& \mathrm{D}$ in the industries. This is a basic transitional process in national innovation system and knowledge creation. The policymaker must take into account the steps needed to stimulate commercialization and promote the relevancy of universities in R\&D to industries.

Malairaja and Zawdie (2008) studied on companies that have links with universities generate higher productivity, better market share, better product and service quality as well as better cost competitiveness than companies that don't have links with universities. The usefulness of this link is translated as the fundamental in developing science parks where firms are mostly conducting R\&D and enjoy the spillover knowledge as a result of having collaboration with local universities. The government of Malaysia allocates funds to most of the universities in term of technology procurement, equipment and services which in turn will provide plenty opportunities to local businesses to capitalize on the innovation knowledge capture the technology-based businesses (Malairaja \& Zawdie, 2008). The industries on the other hand, take advantage on the feedbacks from the universities to improve their product and services. Research grants from the government however, is an important tool to expedite the collaboration process. It will catalyze the universities-industries interaction. However, perception that university research is not relevant to SMEs is one of the prime reasons. Other reason is the universities and research institutes have very limited relevant services to offer to the related industries and the industries do not consider the collaboration as an important factor in decision making. Another possible reason is that the universities prefer to deal with more established companies for reasons of bigger research grants, prestige and absorptive capacity.

General perception that companies do not see a real benefit of paying higher taxes should be abolished if a proper mechanism is implemented to allow the company access to better advice and expertise from the universities. Proactive consultancy relating to strategic, organizational, and technological weaknesses are essentials and often the firms are unaware of such deficiencies (Kaufmann \& Tödtling, 2002). Collaboration with universities could involve in 
Volume 3 Issue 9 (September 2021) PP. 228-243

DOI 10.35631/AIJBES.39016

product innovation and solutions that are related to their business. They will exchange technological knowledge from the scratch until they come up with an innovative product that will be ready to be commercialized. This is a continuous cycle because once the products enter the market, the industries will generate revenue. The government will impose tax on this revenue which later part of it will be given back as research grant that would benefit the industries and the universities. As such, innovation of products and services will flourish. This is called Research Ecosystem.

This Research Ecosystem will work well in Malaysia if the government has allocated enough funds for R\&D activities primarily for industrial driven research conducted by the universitiesindustries joint venture. This is to invent and innovate products that are viable for commercialization and in line with the needs of the industries and market. The governmentindustries-universities triple helix culture (Saad \& Zawdie, 2005) could eliminate unnecessary off course research that is not feasible. However, the system can only work if the universities have been provided with proper industry and market targets while the industries must understand the extent of product innovation that can be carried out by the universities using the available technologies, research and knowledge. If not, there will exist a condition where universities are keeping on adding numbers of patterns to their shelves products that may have commercial value but since the links are not exist, the industries are not informed, and the valuable products are buried unnoticed.

Without efficient tax cut benefit, some Foreign Multi-National Corporation (MNC) companies might have taken advantage of bringing home their profit generated in Malaysia to evade paying high taxes in Malaysia. In view of this, the establishment of Research Ecosystem in Malaysia is promoted as the medium for collaboration between foreign MNCs with local universities using grants from the introduced tax incentives. The policymaker must view this grant as an important instrument because in the long run it will benefit the industries, universities and the nation as a whole. In the era of modern economics as stated by (Czarnitzki et al., 2011), directly or indirectly various policy instruments are employed by the government to foster R\&D and innovation in the business sector by providing direct grants and tax credits to support private investment in R\&D. Researchers in innovation have indicated that the lower effect of innovation investment is a result of market failures. The first reason is that some firms are unwilling to invest on some innovation that might be copied by their rival although the invention is for the good of the public. The second reason is the uncertainty of the innovation investment whether it would be marketable and profitable as against to other ordinary investments that are tangible. Thus, tax cut in the form of R\&D incentive is a preferable way to instill freedom of innovation utilizing the available resources to optimize the revenue. This is affirmed by Lim et al. (2012) that the firms' allocation of funds on innovation programs are a significant determinant in the performance of the firm in innovation. The higher spending on innovation would generate a better innovation program.

\section{$R \& D$ Tax Incentives in Malaysia}

Previous studies largely limited to manufacturing industries although it has been over 30 years the researches relating to the effect of tax incentives on R\&D. Most of the studies are found to be experimental and provide various diversified effects that sometimes dissimilar and unrelated. A few points that can be derived from these studies are different countries have their own different methods of allocating tax incentives on R\&D depending on which sectors they need to empower the most (Gokhberg, Kitova, \& Roud, 2014). Size of the countries, size of the budgets and the quantity of resources also affect the tax implementation. An agricultural- 
Volume 3 Issue 9 (September 2021) PP. 228-243

DOI 10.35631/AIJBES.39016

based country would have a different mechanism than those industrial-based country. Some countries would spend R\&D more on product innovation while in some countries the industries might use the grants from the tax incentives to optimize the resources.

In Malaysia, the government has introduced several tax cuts and reliefs as well as tax incentives to several sectors such as agriculture, education, tourism and industrial amongst others. If some percentage of the tax could be given back to the companies, the companies would be less burdened on spending R\&D on innovation. As a result, more innovative products will come up and increase the revenue of the company which in the end the government will benefit for taxing a bigger sum. Government could use the tax incentive mechanism to inspire innovators in SMEs to have their own R\&D departments such as by giving them tax incentives for acquiring R\&D equipment. Chandran et al. (2014) found out that Malaysia's policy focuses on offering incentives and better infrastructure with the aim to draw foreign investments where the government focused at collaborating MNCs with local firms. Although the universities are allocated with $R \& D$ funding resources, the universities are out of the picture and a missing link exists. The local firms gain technological know-how only from the interaction and linkages with MNCs. It is a proof of an unfortunate university-industry collaboration. Although interviews on the field shows that universities see that the vital source of knowledge comes from the industries, however the industries see the otherwise. A few reasons that emerge are cultural differences, weakness of organizational practices in universities and above all is the existing gaps in the nature of R\&D observed by universities and industries. Investment in R\&D might also reflect the absorptive capacity of the industries in assimilating and identifying the new knowledge.

\section{Tax Incentives, $R \& D$ and Innovation}

Tax incentive for R\&D is considered as a main public policy and instrumental to reach the objective to increase private firm's investment in R\&D (Castellacci \& Lie, 2015). It has a positive outcome because the bigger the spending on $R \& D$, more tax incentives are gained to lower its marginal cost. However, it is revealed that in micro-econometric studies tax incentives has a smaller effect on sub-sample high-technology industries but higher in countries that have incremental scheme such as Japan, US and France. Brown, Martinsson, and Petersen (2017) mentioned the cross-industry association between the characteristics of the alternative industry which indicates that innovation programs moving in tandem with external finance but moving in the opposite direction with cash flow and income tax. If the company is having a high cash flow and low external finance, the company is also found to be high in income tax and therefore less expenditure on R\&D. As such, some innovators in private sector would run dry on financing the R\&D on innovation. This circumstance creates an innovation gap and needs interference from the government who would help in the form of subsidies and tax incentives to minimize the financial burden of companies undertaking R\&D innovation and to build up the companies' effort in innovation. This liquidity constraints always revolve around SMEs or technology intensive sector where R\&D is a big investment.

On the other hand, there also evidences that tax incentives for R\&D have negative differential correlation with R\&D funds invested in high and low innovative intensity industries although there are substantial positive reaction as a response to the introduction of $R \& D$ tax incentives e.g., (Bloom, Griffith, \& Van Reenen, 2002; Hall, 1993) where there is an indication that the effect is much weaker in more innovative sector and R\&D only increases in less innovative industries. The result from the level regression shows that the effect of cost minimizing due to tax incentives is limited to industries which are non-high-tech. One of the reasons is that high- 
Volume 3 Issue 9 (September 2021) PP. 228-243

DOI 10.35631/AIJBES.39016

tech industries are imposed with lower corporate income tax. The other reason is that although more tax incentives for R\&D are introduced, high-tech firms always lag behind. Crespi et al. (2016) indicates that developing countries are taking step in granting tax incentives to enhance the participation of private firms in $R \& D$ and innovation though there is no concrete evidence on the effectiveness of the mechanism would reach the objective. The study which focused on Argentina's firm-level investment in innovation recommends that the elasticity of the investment has a positive effect in increasing the companies' efforts in innovation although the effects might vary depending on the innovation investment that is being subsidized, industrial sector, and size of the firm. Using two waves of Innovation Surveys, the study found that the Argentinean tax incentives has decreased the user cost of capital coefficient for R\&D innovation which shows the decision on innovation investment generated a significant effect. It is also found that in low technology sector, the effectiveness is higher. Further, larger firms which have no constraint on liquidity react faster to the tax incentives as against the smaller firms which have limited capital resources. Other literatures carried out studies in Norway by Ientile and Mairesse (2009) and Hægeland and Møen (2007) to examine the relationship and relative efficiency of R\&D subsidies and the tax incentives. They found out that the subsidies and tax incentives are complement at firm-level but become substitutes at economy-level. Moreover, the researchers indicate that tax incentives to private firms create more additional R\&D than subsidies. Koga (2003) found that tax price elasticity was about -0.68 when estimating it for 904 Japanese manufacturing firms over a period of 10 years (1989-1998) when studying the effectiveness of tax incentives on R\&D which suggested that the mechanism was effective in increasing R\&D investment. Similar mechanism could be promoted to be exercised in Malaysia.

\section{Practices and PoliciesiIn Developed Countries}

According to Freitas, Castellacci, Fontana, Malerba, and Vezzulli (2017), tax incentive for R\&D has benefited more than 20 OECD countries. The firms can apply for direct reductions from the company tax so as to reduce the cost and expand the existing R\&D programs (OECD, 2010). Tax incentives on $R \& D$ are not the same as $R \& D$ subsidies because of their different advantages and disadvantages (Ientile \& Mairesse, 2009). R\&D tax incentives are only applicable to companies that have invested in particular fields that are exempted by the tax and the investment must be viable to produce positive profit that is taxable. It is considered as a market intervention policy, therefore there is a space for an appropriate evaluation on the effectiveness of tax incentives towards R\&D innovation. Tax incentives provide liberty to the firms in selecting and financing to carry out their R\&D programs. Subsidies have a centralized authority where decision making is delegated and not efficient in maximizing profit.

The number of countries implementing tax incentives for R\&D are increasing. Tax incentive becomes a popular government policy in OECD country members (Gokhberg et al., 2014). The tax incentives and other complimentary methods that are engaged to assist the development of SMEs, start-ups, particular priority R\&D areas, economic industries and other sectors of the national innovation system include; tax incentives for companies to reduce their tax depending on how much they spend on R\&D or growth; accelerated depreciation of R\&D machinery, equipment, buildings, structures and other intangible assets; tax exemption on selected R\&D spending including over $100 \%$ of the amount; reduced income or social taxes or total tax exemption for the company's staff carrying out R\&D or particular categories of staff; and the cut back or exception from companies' income tax for income gained from R\&D results. In Japan for example, the innovation culture is supported by the system involving tax, university and private sectors. Innovation is part of their practices and have succeeded to continuously Copyright $\odot$ GLOBAL ACADEMIC EXCELLENCE (M) SDN BHD - All rights reserved 
emphasize the importance of them. Companies that pay taxes are entitled to utilize a certain percentage which is approximately $10 \%$ of the corporate tax paid as research grants. This entitlement awards them liberty to engage any universities to provide products or solutions related to their business activities. Universities are paid using the research grant. The higher the tax, the higher the entitlement given to the company. With this huge fund, many universities can participate in producing innovative products requested by the companies that team up with them. This will enhance the exchange in knowledge of technologies between academic world and industry. Universities will compete as well as collaborate among each other to fulfill the request of the industries. Once a new product was born, the industry is ready to proceed with pre-commercialization and finally commercializing them.

Chandran et al. (2014) studied on the use of Multi National Corporation (MNC) as the tool for technological upgrading is a result of policy differences. In South Korea the policy is designed to assist technological programs. In Taiwan the policy is aiming for creating dynamic local SMEs. Significantly however, active companies in R\&D programs circulated amongst selected industries only such as manufacturers of electronics, petroleum and transport equipment but still at minimal level if compared to other emerging economies such as China, Taiwan and Korea. Eom and Lee (2010) found that in Korea there is a positive effectiveness of university collaboration only in the sample of innovating firms which means that the impact is significantly visible if the company involved in innovation programs.

Findik and Beyhan (2015) assessed the innovation activities of firms in Turkey for a period between 2006 and 2008 using innovation survey carried out by Turkish Statistical Institute in 2009 to study how collaborations have affected the innovation performance of firms. The findings show that there is a positive correlation between external collaboration and the effect of product innovation where the production process, product and market are enhanced. External collaboration has positive and important impact both perceptions associated with the productoriented and process-oriented effect of innovation. In the research, it is accentuated that large firms tend to innovate more than small firms (Rogers, 2004). Other study by (Ettlie \& Rubenstein, 1987) found that large firms emphasize more on process innovations which turn into product innovations rather than introducing new products. It is also noted that the introduction of new products needs more external funding as opposed to implementing new processes. On the other hand, Chen and Gupta (2017) indicated that the increase in the R\&D tax incentives rate has a positive effect on the R\&D spending of high-tech firms, but not on the non-high tech firms considering tax incentives could not the only way to achieve the policy target. One of the reasons is that the opportunity for innovation could be the major drive for the tax incentives. The other reason is the incentive structure affects the firms' R\&D spending patterns. Their study shows that tax incentives that are associated to incremental R\&D spending giving opportunity to firms to adjust their spending schedule patterns in order to maximize their tax incentives to the extent if the aggregate spending over that time period is unchanged, the unintentional effect of such timing could be higher than the expected loss of revenue in tax.

It was reported by Szczygielski et al. (2017) that Turkey and Poland had added their grant offering of innovation programs in order to increase their companies' innovation performance. These two countries had known for the equal level of economic improvement. In addition, a 2010 innovation survey data discovered that both countries were benefited more of their innovation performance when they received an assistance in $R \& D$ programs from the government as compared to the assistance of physical and human capital from EU-funded grants. The EU-funded grants had been seen inefficient to foster innovation while became a Copyright (C) GLOBAL ACADEMIC EXCELLENCE (M) SDN BHD - All rights reserved 
Volume 3 Issue 9 (September 2021) PP. 228-243 DOI 10.35631/AIJBES.39016

reason that hampered innovation. Policy conclusions for what we call "technology-follower countries with relatively well-developed institutions" are suggested. However, this relates only to the grants allocated by domestic sources (local or national governments), while the role of EU-allocated programs is statistically at minimal or negative. In Turkey, the result could be associated to the small number of surveillances than it does for Poland, which obtained its innovation policy mainly from the European Union's structural programs. However, a lot of that EU support has been paid out on subsidizing the upgrading of physical and human capital in Polish firms. It is affirmed that Poland and Turkey had justified that financial support for R\&D programs such as grant from government or local were conducive for them to improve their innovation performance level, which is indicated by three aspects of innovation of products which is new to the market and new to the firm, and innovation of process.

\section{Existing Problems in Malaysia}

\section{Malaysian-Based Companies}

Malaysian SMEs are struggling to invent new and targeted market demand for innovative product even with various supports from the government with only limited SMEs are aware of the benefits of innovation (Nor et al., 2017). The research identifies the barriers that deter the process of innovation by examining innovation and performance of food processing of SMEs in Malaysia. Innovation is achieved through product development (Vermeulen, O'shaughnessy, \& De Jong, 2003). Their study indicated that the focus of previous researches on innovation were more on large firms and left out small firms. However, small companies need to compete with other established companies by offering product and services of better quality to the customer. In view of this, they need to continuously innovate to be constantly improved and bring out innovative product (Simon, Houghton, \& Aquino, 2000). Jani and Alam (2011) discovered various factors that hinder food processing based SMEs from conducting R\&D innovation. Kaufmann and Tödtling (2002) indicated that the SMEs are confronted with innovation problems. The most cited problems are most SMEs hardly interact and collaborate with knowledge sources outside their business sector (e.g., universities) and they have little interaction with innovation-related resources and external information.

\section{Government Funding/Grant}

Lee and Chew-Ging (2007) explains that private sector firms acquire funds for innovation programs from internal or own resources referring to MASTIC's R\&D surveys since 1994. R\&D in Malaysia views government as a less important source of funding. Malaysian SMEs are having hard time sourcing their financial needs either from the government or financial institutions; whereby they are subjected to bureaucratic red tapes, high interest rate or profit charged, complex loan process and ill-informed by financial institutions. Other related problems are human capital, business competitiveness, infrastructure, and government policy (Nor et al., 2017). The study suggested for the Malaysian SMEs to be competitive globally and remain sustainable, they must be provided with sufficient financial supports either from the government or from the financial institutions to produce new products and discover new supply sources.

\section{Government Support in Malaysian Research and Innovation Culture}

Lee and Chew-Ging (2007) in their study showed since the mid-1990s National surveys of innovation and R\&D have been routinely carried out in Malaysia. These surveys recommend that the proportion of innovating firms in the manufacturing sector is between 21 and 42 per cent. These surveys also indicate that finding sufficient funds is a hard task for innovating firms 
Volume 3 Issue 9 (September 2021) PP. 228-243

DOI 10.35631/AIJBES.39016

while micro enterprises and SMEs experience much worse because they are mostly soleproprietorship or partnership firms with confined access to the capital market. The government however, has reacted to this situation by supporting them in the form of various tax incentives and direct financial grants. The surveys further recommend that SMEs and micro enterprises would be the major beneficiaries of financial grants. Large firms prefer the double tax deductions advantage while micro-enterprises and SMEs discover import duty exemptions are more beneficial. In general, although only a small number of firms that has been given fiscal and financial support by the government, many firms surveyed view government support for innovation and technology to be essential and looking forward to have a favorable government policy that cater for the Malaysian SMEs' innovation. Lee and Chew-Ging (2007) also found in a survey that there was insufficient assistance for new product development of local SMEs which represented by $47 \%$ agreement among the respondents. Whereas, another indicator showed that about $57 \%$ disagreement came from the respondents pertaining the government policy in assisting SMEs, where there was lacking in financial helps, incentives and grants.

According to Lim et al. (2012) the support from the government shows a significant effect on firms' investment in innovation activity, but it depends on the support type. The low number of a statistically significant effect of government financial support may be because of the larger proportion of medium and large sized firms among the receivers of such aids, as always it has been the small sized firms that have positive effect.

\section{Research Ecosystem Model}

The research ecosystem proposed in this paper consist of interaction among three main actors; the government, industry, and university. The ecosystem starts when companies pay an imposed tax to the government thus enabling them to receive entitlement for research grants. With the research grants entitlement by the government, the companies will request a university to conduct a research for new products or services according to the companies' requirement. The new products or services are expected to generate new revenues as well as profit for the company where the company play its roles by commercializing the new products. the cycle proceeds with the profit gained being taxed and new entitlement of research grant is available for the company. It will become a new opportunity for the company to produce another new product with the university involvement. The cycle continues where another product is born, getting commercialized, producing profit and taxes paid. This is what is called Research Ecosystem, a system that continuously running non-stop, industrial driven with self-sustaining mechanism benefiting companies, universities and the country as a whole. A clear picture of the proposed research ecosystem is presented in Figure 2. 
Volume 3 Issue 9 (September 2021) PP. 228-243

DOI 10.35631/AIJBES.39016

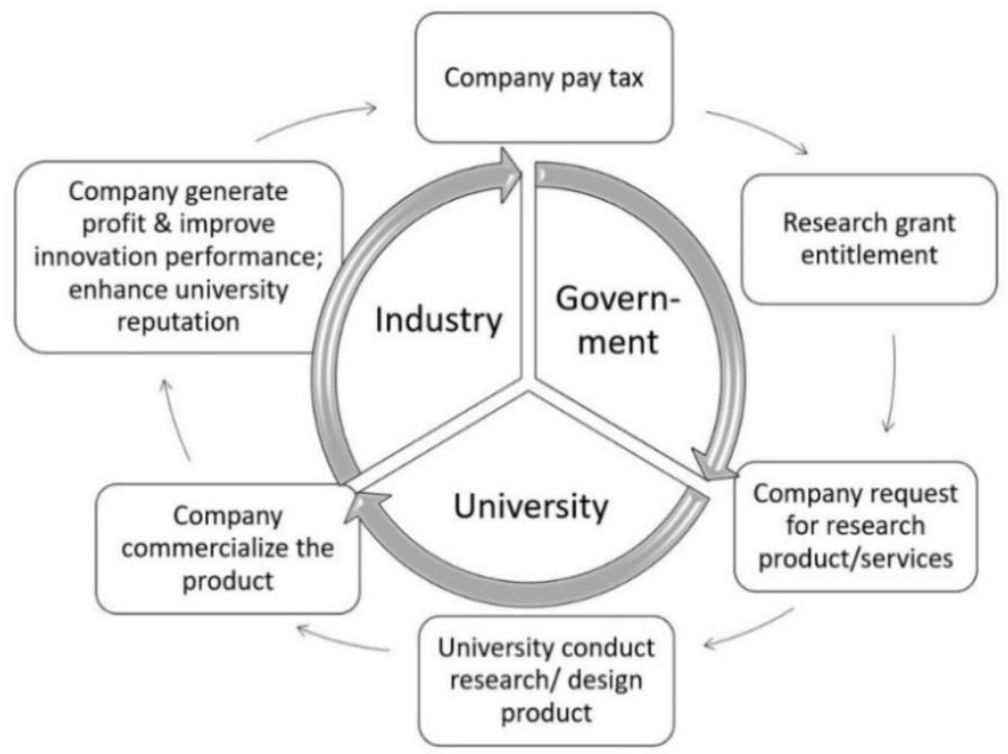

Figure 2: Proposed Research Ecosystem through Tax Mechanism

\section{Challenges}

Each improvement initiative is often accompanied by challenges that need to be overcome. The challenges involved include both external and internal aspects. The challenges are an uncertain beneficiary for R\&D tax incentives imposition, the different capacity of private sectors and nature of $R \& D$ activities, mismatch and poor university-industry relationships, lack of universities and local R\&D institutions roles, lack of intermediary roles, and last but not least the vague policy initiatives by the stakeholders.

\section{Uncertain Beneficiary for R\&D Tax Incentives Imposition}

The questions always linger around who will be benefited more from the tax incentives enforcement. Moreover, an argument made in earlier studies mentioned that the allocated tax incentive given by the government were benefiting the large companies more that the SMEs (Koga, 2003; Lee \& Chew-Ging, 2007). A survey on the R\&D tax credits proved that it has an impact on firms' innovation activities and it varies across different industries (Castellacci \& Lie, 2015; Freitas et al., 2017). Another instance of large panel firms data was done in the industrialized countries showed that firms in France for example, which have a better chance to received $R \& D$ tax credit and benefited more of additionality input effects were the firms that involved in more concentrated market such as science-based and specialized suppliers (Freitas et al., 2017). These arguments made it difficult for the country to justify which sectors and stakeholders are getting what advantages from the implementation of innovation tax incentives since all the private sectors have an obvious difference capacity in terms of technological, human and financial. However, by putting enormous effort, it seems possible to treat all stakeholders equally.

\section{Mismatch and Poor University-Industry Linkages}

Iqbal, Khan, Bashir, and Senin (2015) had made an effort to investigate the Malaysia's innovation system and the factors of its failure from two aspects constraints. They were investigating on lack of the national innovation system itself and also the limitations of university and industry research collaboration. Chandran et al. (2014) who also surveyed and interviewed the relevant respondents in Malaysia regarding their alliance activities between the Copyright (C) GLOBAL ACADEMIC EXCELLENCE (M) SDN BHD - All rights reserved 
Volume 3 Issue 9 (September 2021) PP. 228-243

DOI 10.35631/AIJBES.39016

university and industry found that the poor linkage is because of a huge gap between the entities. The study proposed three main reasons that contributed to the weaknesses of national innovation system structure that are disparity of $R \& D$ events, the fragility of industrial $R \& D$ structure and the absent of intermediary body role. Meanwhile, Iqbal et al. (2015) summarized the lacking of university and industry collaboration are due to the lack of education, limitation in technological competency training and consultancy, intellectual property rights conflict, time and cultural limitations, fund and financial difficulties. The challenge is to reduce the mismatch linkages between university and industry. It is believed if both of the entities are deliberately working on reducing the gap and make and effective efforts, the collaboration activities between the two can achieve success (Chandran et al., 2014). Even so, without a proper government policy and infrastructure, a poor collaboration of university and industry can still be happening.

\section{Different Nature of $R \& D$ Activities Between University and Industry}

R\&D activities involved when the companies are having an innovation attempt whether in a products, processes or services. Chandran et al. (2014) found out there is a gap of R\&D activities between university and industry. It actually refers to the nature of R\&D activities among these parties itself. Universities had been recognized for its core business, which is beside teaching, they also engage in doing research. However, the kind of research and development involved basically a very fundamental and rudimentary. Whereas, looking from the industry's side, firms are mostly involved with an incremental innovation, a small yet consistent improvement towards any current products, processes or services. This kind of innovation only entails with lower R\&D venture. The nature of their absorptive capacity are also different (Chandran, Farha, \& Veera, 2008). Private firms are known for their business structure that are capable to absorb as much as relevant technologies into their companies and some of them are very dedicated to performing improvement efforts inside the business. However, universities on the other hand are lacking at so many angles, for example, they do not have the consistent right capital to receive so much knowledge or technologies to make the changes. Furthermore, when look at the angle of R\&D collaboration of industries, firms tend to have closer linkages with their external customers such as purchasers, suppliers and also the technical service companies in performing their R\&D. Firms need to acquire feedback and support from these external customer for a better input into their R\&D. The information comes from these linkages seems to have practical advantages as compared to the knowledge or information shared from the universities, thus making the universities are the least favorable $\mathrm{R} \& \mathrm{D}$ collaborator for the industries.

\section{Limited Roles of Universities and Local R\&D Institutions}

University and local R\&D institutions are part of the triple helix structure of innovation ecosystem between the government, industry and university. These three stakeholders are responsible to play their roles in collaborating to each other to make the innovation ecosystem a success. However, challenges rise when the industries acknowledged the limited roles of universities and local R\&D bodies. In a survey on the industries, the two parties were rated as the least significant sources of information for innovation efforts (Koga, 2003; Lee \& ChewGing, 2007). Malaysian universities' are bound to provide consultation only (Chandran et al., 2008), while the local R\&D bodies are seen to be inefficient in assisting technological capabilities enhancement of the local firms (Malairaja \& Zawdie, 2008). Universities are also acknowledged for theirs lacking in absorptive capacity (Chandran et al., 2014). Other than that, there is also a concern on the privacy issues where, innovation information shared by the private firms to the university are feared to be disclosed to the competitors. Due to this lacking, it is a 
Volume 3 Issue 9 (September 2021) PP. 228-243

DOI 10.35631/AIJBES.39016

challenge to convince the industries to put a trust on the other components of the innovation ecosystem in order to perform all in all $\mathrm{R} \& \mathrm{D}$, innovations and commercialization thus making the firms to trust more on their chain of supply relationship to provide information for innovation activities (Iqbal et al., 2015).

\section{Lack of Intermediary Roles}

The collaboration between university and industry must be strengthened to achieve enhancement of research outputs' commercialization (Malairaja \& Zawdie, 2008). However, this relationship has been seen as lacking without any intermediary roles. The collaboration between university and industry was argued to be weak without the interference of intermediary in coordinating and managing the collaboration (Chandran et al., 2008; Chandran et al., 2014). It is suggested that the intermediary body must be the one who is properly appointed so that all research, innovation and commercialization activities between university and industry can be appropriately managed and coordinated (Chandran et al., 2014). Beside commercializing the research output, other activities that have the potential to be conducted such as organizing programs that can assist firms in the incubator university to internationalize their business (Saad \& Zawdie, 2005). Link and Rees (1990) claimed that small firms are the one who benefited most from the university-based research linkages since they are more innovative as compare to the large companies. This shows that large companies are possibly undermine the potential of university-based research to be incorporated into their internal R\&D activities. The issues discussed raises the question of whether the role of technology transfer office is needed in this matter as the intermediary body between the industry and university. Whether this body can help increase the confidence of all size of private sectors into the linkages with university is still long for a solution. Moreover, the availability of this platform in all universities is still in question.

\section{Vague Policy Initiatives}

A rigorous study on the national innovation system proved that the lacking on university and industry collaboration of research significantly influenced the success of national innovation system (Iqbal et al., 2015). It has been long proposed by previous research to come with the solution of innovation ecosystem by fostering the triple helix culture as what have been practiced in many developed and industrialized countries (Chen \& Gupta, 2017; Crespi et al., 2016; Gokhberg et al., 2014; Hægeland \& Møen, 2007; Saad \& Zawdie, 2005). The entities of triple helix involves the government, industry and university (Saad \& Zawdie, 2005). These three components are crucial to make their effort towards the success of the proposed innovation ecosystem for the national innovation system. The ambiguity of collaboration effectiveness of university-industry coupled with the lack of initiative by the industry to collaborate make innovation ecosystem accomplishment a major challenge (Chandran et al., 2014). Policy initiative by the government is look to be the most stimulating key to the enforcement of research innovation ecosystem that make use of tax incentive for R\&D and innovation activities. However, the challenge is to identify and structure the policy so that it could be concentrated to the sectors and industries that probably have a strong impact on the national economy (Castellacci \& Lie, 2015)

\section{Conclusion and Recommendations}

The new products are expected to generate new revenues as well as profit for the company. The profit will then be taxed, and new entitlement of research grant is available for the company. It became a new opportunity for the company to produce another new product with the university involvement. Another new product is born; get commercialized, produce profit, 
Volume 3 Issue 9 (September 2021) PP. 228-243 DOI 10.35631/AIJBES.39016

pay taxes and the cycle continues. This is what is called Research Ecosystem, a system that continuously running non-stop, industrial driven with self-sustain mechanism benefiting companies, universities and the country as a whole. While we find many positive responses on the enforcement of tax incentives mechanism upon R\&D and innovation improvement, thus granting us an idea to propose the same method to be fully enforced in the context of Malaysia. As the tax incentives are found to benefit largely the research ecosystem in large companies, it should become the base for future policies to emulate and apply on R\&D in SMEs to enrich their innovation and product commercialization. This paper concludes that recent research ecosystem in Malaysia does not fully developed which might affect economic performance indicators such as profitability, productivity, sustainability and market shares. Further research would be benefited to have panel data on R\&D tax incentives and performance indicators based on objective measures to complement the current imperfect research environment involving the government, industry and the university.

\section{Acknowledgement}

The authors would like to extend their gratitude to Universiti Tun Hussein Onn Malaysia for financial support. All those who contributed direct and indirectly are thanked.

\section{References}

Ankrah, S., \& Omar, A.-T. (2015). Universities-industry collaboration: A systematic review. Scandinavian Journal of Management, 31(3), 387-408.

Bloom, N., Griffith, R., \& Van Reenen, J. (2002). Do R\&D tax credits work? Evidence from a panel of countries 1979-1997. Journal of Public Economics, 85(1), 1-31.

Brown, J. R., Martinsson, G., \& Petersen, B. C. (2017). What promotes R\&D? Comparative evidence from around the world. Research Policy, 46(2), 447-462.

Castellacci, F., \& Lie, C. M. (2015). Do the effects of R\&D tax credits vary across industries? A meta-regression analysis. Research Policy, 44(4), 819-832.

Chandran, V., Farha, A., \& Veera, P. (2008). The commercialization of research results among researchers in public universities and research institutions. Asian Profile, 36(3), 235250.

Chandran, V., Sundram, V. P. K., \& Santhidran, S. (2014). Innovation systems in Malaysia: a perspective of university-industry R\&D collaboration. AI \& SOCIETY, 29(3), 435444.

Chen, M.-C., \& Gupta, S. (2017). The incentive effects of R\&D tax credits: An empirical examination in an emerging economy. Journal of Contemporary Accounting \& Economics, 13(1), 52-68.

Crespi, G., Giuliodori, D., Giuliodori, R., \& Rodriguez, A. (2016). The effectiveness of tax incentives for R\&D+i in developing countries: The case of Argentina. Research Policy, 45(10), 2023-2035.

Czarnitzki, D., Hanel, P., \& Rosa, J. M. (2011). Evaluating the impact of R\&D tax credits on innovation: A microeconometric study on Canadian firms. Research Policy, 40(2), $217-$ 229.

Eom, B.-Y., \& Lee, K. (2010). Determinants of industry-academy linkages and, their impact on firm performance: The case of Korea as a latecomer in knowledge industrialization. Research Policy, 39(5), 625-639.

Ettlie, J. E., \& Rubenstein, A. H. (1987). Firm size and product innovation. Journal of Product Innovation Management, 4(2), 89-108. 
Volume 3 Issue 9 (September 2021) PP. 228-243

DOI 10.35631/AIJBES.39016

Findik, D., \& Beyhan, B. (2015). The impact of external collaborations on firm innovation performance: Evidence from Turkey. Procedia-Social and Behavioral Sciences, 195, 1425-1434.

Freitas, I. B., Castellacci, F., Fontana, R., Malerba, F., \& Vezzulli, A. (2017). Sectors and the additionality effects of R\&D tax credits: A cross-country microeconometric analysis. Research Policy, 46(1), 57-72.

Gokhberg, L., Kitova, G., \& Roud, V. (2014). Tax incentives for R\&D and innovation: demand versus effects. Foresight-Russia, 8(3), 18-41.

Hægeland, T., \& Møen, J. (2007). The relationship between the Norwegian R\&D tax credit scheme and other innovation policy instruments. Statistics Norway report 2007/45.

Hall, B. H. (1993). R\&D tax policy during the 1980s: success or failure? Tax policy and the economy, 7, 1-35.

Ientile, D., \& Mairesse, J. (2009). A policy to boost R\&D: Does the R\&D tax credit work? EIB papers, 14(1), 144-169.

Iqbal, A. M., Khan, A. S., Bashir, F., \& Senin, A. A. (2015). Evaluating national innovation system of malaysia based on university-industry research collaboration: A system thinking approach. Asian Social Science, 11(13), 45.

Ismail, K., \& Soehod, K. (2014). National Survey of Innovation 2012. Putrajaya, Malaysia: Malaysian Science and Technology Information Centre

Jani, M., \& Alam, S. (2011). Barriers of Innovation of Food Processing Smis in Malaysia: An Emperical Study. National University of Malaysia, UKM Bangi, Malaysia.

Kaufmann, A., \& Tödtling, F. (2002). How effective is innovation support for SMEs? An analysis of the region of Upper Austria. Technovation, 22(3), 147-159.

Koga, T. (2003). Firm size and R\&D tax incentives. Technovation, 23(7), 643-648.

Lee, C., \& Chew-Ging, L. (2007). Encouraging innovation in Malaysia. CACCI Journal, 1(1).

Lee, C., \& Lee, C.-G. (2007). SME innovation in the Malaysian manufacturing sector.

Lim, E. S., Lee, C., \& Nagaraj, S. (2012). The Relationship Between Innovation and Firm Performance: Evidence from Malaysian Manufacturing Firms. Paper presented at the Asian Business and Management Conference, Osaka, Japan.

Link, A. N., \& Rees, J. (1990). Firm size, university based research, and the returns to R\&D. Small Business Economics, 2(1), 25-31.

Malairaja, C., \& Zawdie, G. (2008). Science parks and university-industry collaboration in Malaysia. Technology Analysis \& Strategic Management, 20(6), 727-739.

MASTIC. (2019). National Research and Development (R\&D) Survey. Retrieved from https://mastic.mestecc.gov.my/statistic/sti-trends/national-research-developmentsurvey

Nor, N. G. M., Bhuiyan, A. B., Said, J., \& Alam, S. S. (2017). Innovation barriers and risks for food processing SMEs in Malaysia: A logistic regression analysis. GeografiaMalaysian Journal of Society and Space, 12(2).

OECD. (2010). R\&D tax incentives: rationale, design, evaluation. In. Paris: November.

OECD. (2018). OECD review of national R\&D tax incentives and estimates of R\&D tax subsidy rates, 2017.

Rogers, M. (2004). Networks, firm size and innovation. Small Business Economics, 22(2), 141153.

Saad, M., \& Zawdie, G. (2005). From technology transfer to the emergence of a triple helix culture: The experience of Algeria in innovation and technological capability development. Technology Analysis and Strategic Management, 17(1), 89-103. 
Volume 3 Issue 9 (September 2021) PP. 228-243

DOI 10.35631/AIJBES.39016

Simon, M., Houghton, S. M., \& Aquino, K. (2000). Cognitive biases, risk perception, and venture formation: How individuals decide to start companies. Journal of Business Venturing, 15(2), 113-134.

Szczygielski, K., Grabowski, W., Pamukcu, M. T., \& Tandogan, V. S. (2017). Does government support for private innovation matter? Firm-level evidence from two catching-up countries. Research Policy, 46(1), 219-237.

Vermeulen, P. A., O'shaughnessy, K., \& De Jong, J. P. (2003). Innovation in SMEs: An empirical investigation of the input-throughput-output-performance model. EIM, Zoetermeer. 